\title{
Personality Trait Differences between Traditional and Social Entrepreneurs
}

Rachael Smith ${ }^{a}$, Robin Bell ${ }^{b}$, Helen Watts ${ }^{b}$

${ }^{a}$ Edmonton County School, Enfield, Middlesex, UK

bWorcester Business School, University of Worcester, Worcester, UK (r.bell@worc.ac.uk)

Social Enterprise Journal, Vol. 10, No. 3, pp. 200-221. http://doi.org/10.1108/SEJ-08-2013-0033

\begin{abstract}
Purpose

This research seeks to identify personality trait differences between social and traditional entrepreneurs.
\end{abstract}

\section{Design/Methodology}

The Durham Business School's General Enterprise Tendencies (GET) test was chosen to measure an individual's entrepreneurial personality. The choice was based on the test's established use within industry and its ability to measure traits most commonly considered 'entrepreneurial' by the extant literature. The test was adapted for this study and distributed to both social and traditional entrepreneurs. The results were then statistically analysed to test for significant differences between the two groups.

\section{Findings}

It was found that social entrepreneurs exhibited statistically significantly higher levels of creativity, risk taking, and need for autonomy than traditional entrepreneurs. The results were then discussed critically in light of the literature.

\section{Limitations}

The modest sample size was the main limitation of the research. In addition, the sample set was fairly culturally homogeneous. It has been recommended that an additional test be carried out with a larger sample size, consisting of a more culturally diverse range of participants, in order to improve the generalisation of the findings.

\section{Originality/Value}

This research provides new insights into personality trait differences between social and traditional entrepreneurs and is particularly useful to those with an interest in entrepreneurial orientation and those interested in the identification and development of social entrepreneurs.

\section{Keywords}

Social Entrepreneurs, Social Enterprise, Entrepreneurial Traits, Entrepreneurial Orientation, General Enterprise Tendencies (GET)

This article is (c) Emerald Group Publishing and permission has been granted for this version to appear here. Emerald does not grant permission for this article to be further copied/distributed or hosted elsewhere without the express permission from Emerald Group Publishing Limited. 
Smith, R., Bell, R., \& Watts, H. (2014). Personality trait differences between traditional and social entrepreneurs. Social Enterprise Journal, 10(3), 200-221. http://doi.org/10.1108/SEJ-08-2013-0033

\section{Introduction}

The turn of the $21^{\text {st }}$ Century catalysed an entrepreneurial revolution, i.e., a new order of enterprise departing from the established paradigm of classical or "Brontosaurus" capitalism (Timmons, 1999). Larger firms recognised the need to be more adaptable and more entrepreneurial in their business approach in order to react to constant changes and new threats in the business environment. Doing business in this manner has become simpler as a consequence of globalisation and developments in technology, which created unprecedented levels of global interconnectivity. Entrepreneurs have established themselves as a group who could cope with the pressures and constrictions of austerity brought on by the global financial crisis, and make progress despite external conditions (Burns, 2012).

Societal issues related to education, health, and public and social justice increased in scale and intensity as a result of the global financial crisis, while governments lacked the resources necessary to address societal problems. In addition, the global financial crisis has seen the priorities of governments and businesses shift away from addressing social issues and towards programs of austerity (Bornstein and Davies, 2010). Just as the traditional entrepreneur brought innovation and enterprise into his business strategies in order to survive the recession, the social entrepreneur has addressed issues of public concern by employing the same commercial and enterprising techniques. Social entrepreneurship has developed into the mainstream after years on the periphery of the nonprofit sector (Gawell, 2013; Urban, 2008). However, it has remained an under-researched field of academic study (Austin et al., 2006).

This research aims to discover the inherent differences in personality traits between traditional and social entrepreneurs. There is little research investigating the differences between these two types of entrepreneur, and acquisition of this knowledge would provide quantitative support for the premise that social entrepreneurs are a distinct group from traditional or commercial entrepreneurs.

\section{Literature review}

\section{Defining the Traditional and Social Entrepreneur}

Kilby (1979) compared the entrepreneur to a fictitious "Heffalump" in the children's story "Winnie the Pooh." Despite the Heffalump being a well know creature, if anybody was questioned about its "particularities," such a diverse range of answers was given that no consensus could be reached about the creature's constitution. Despite this, anyone could identify the Heffalump if he saw it. 
Smith, R., Bell, R., \& Watts, H. (2014). Personality trait differences between traditional and social entrepreneurs. Social Enterprise Journal, 10(3), 200-221. http://doi.org/10.1108/SEJ-08-2013-0033

Attempting to compile an accurate and comprehensive list of traits by which to identify the entrepreneur proves equally difficult.

In the literature, there is considerable debate regarding the exact definition of the term "entrepreneur" (Bolton and Thompson, 2004; Stokes et al., 2010). Many definitions can be drawn from the literature, ranging from those that include all business owners and managers who have established a start-up (Onuoha, 2007), to definitions that focus primarily on fiscal aspects such as capital gain, exploiting market opportunities, and economic growth (Schumpeter, 1965).

This study uses a relatively inclusive definition. Bolton and Thompson (2004) define the entrepreneur as "a person who habitually creates and innovates to build something of recognised value around perceived opportunities." They emphasise that the defining characteristic of an entrepreneur is not necessarily the pursuit of wealth or combination of personality traits that would traditionally render them entrepreneurial, but rather the leveraging of all resources from the micro and macro environment with the potential to add value and advance or establish a given venture. The entrepreneur does this regardless of whether the perceived opportunity or venture results in the creation of economic, aesthetic, or social capital. Accordingly, this study will use Bolton and Thompson's definition of an entrepreneur.

As with the traditional entrepreneur, there is no universally accepted definition of the social entrepreneur. Indeed, Mason (2012) highlights the "seemingly endless definitional debate amongst academics" as to the precise nature and definition of social entrepreneurship, and Haugh (2005) suggests that social entrepreneurship research has not been well served by the many terms and definitions adopted by researchers and policy makers. For the purpose of this research, the social entrepreneur is considered to be one who seeks to maximise social value or social capital from nonprofit pursuits, creating economically sustainable solutions for social problems (Tracey and Phillips, 2007), and that social entrepreneurs can operate from within existing social enterprises, form new charities, community interest companies, and/or non-profit enterprises of all descriptions.

Although the literature often considers the social entrepreneur to be a sub-species of the traditional entrepreneur (Ersnt, 2012), success for the social entrepreneur and the respective enterprise is measured not solely by cost efficiency and profit (Stokes and Wilson, 2010), but by the extent to which the venture is achieving egalitarian and socially legitimate goals (Wickham, 2006). According to Jones et al. (2008) the traditional entrepreneur seeks private or shareholder gain whilst the social 
Smith, R., Bell, R., \& Watts, H. (2014). Personality trait differences between traditional and social entrepreneurs. Social Enterprise Journal, 10(3), 200-221. http://doi.org/10.1108/SEJ-08-2013-0033

entrepreneur seeks to enhance social value. For the social entrepreneur, society acts as the integral stakeholder for which gains are sought. Essentially, a social entrepreneur employs the same commercial techniques and strategy utilised by the traditional entrepreneur, but for the advancement or start-up of a socially-oriented venture (Pomerantz, 2003). Social entrepreneurs can operate on their own or as a member of special projects created out of a larger organization (Germak and Robinson, 2013). Importantly, although social entrepreneurship may share some of the characteristics of commercial entrepreneurship, social entrepreneurship is a distinct form of entrepreneurship (Austin et al, 2006). This was supported by Duncan (2009) who concluded from a qualitative study of established social entrepreneurs that social entrepreneurs were a distinct group compared to commercial entrepreneurs. This quantitative research seeks to test whether this distinction can be confirmed using the GET test to measure the comparative entrepreneurial traits.

There has been relatively little normative or empirical research established examining differences between social and traditional entrepreneurs. Some body of work attempts to define the characteristics of the respective groups individually, but very few papers focus on a comparison of the two. The limited body of work was made up of conflicting arguments as to the similarities and differences between the two types of entrepreneur.

Some academics have argued that entrepreneurial and social personalities are incompatible (Arribas et al. 2012; Cho, 2006). They assert that traditional entrepreneurs are likely to exhibit high levels of self-interest and low levels of social conscience, which is contradictory to the behaviour of a social entrepreneur. However, this presumes that the use of the term 'entrepreneur' can only be used when an individual seeks economic advantage.

In contrast to this view, other academics have argued that social entrepreneurs are no different in terms of personality or motivation to traditional entrepreneurs, and the only valid difference lies in the values and perceptions underpinning their visions and ventures (Martin and Osberg, 2007).

Ernst (2012) maintains that successful social entrepreneurs possess the same entrepreneurial personality traits as their traditional counterparts (i.e. risk taking propensity, innovativeness, need for achievement, need for independence, and pro-activeness), along with an aspiration to solve issues of a social nature. This prosocial personality, Ernst argues, exhibits higher levels of empathy, and sense of social responsibility than do the personalities of traditional entrepreneurs.

It can be reasoned that social entrepreneurs need to employ entrepreneurial and commercial techniques to advance their ventures in the same fashion as traditional entrepreneurs because it can be shown that they possess many of the traits associated with successful traditional entrepreneur. 
Smith, R., Bell, R., \& Watts, H. (2014). Personality trait differences between traditional and social entrepreneurs. Social Enterprise Journal, 10(3), 200-221. http://doi.org/10.1108/SEJ-08-2013-0033

For example, the ability to identify opportunities and create new markets is a widely acknowledged competency of traditional entrepreneurs (Burns, 2012), and it has been argued that social entrepreneurs use the same skills to solve social problems (Elkington and Hartigan, 2008; Leadbetter, 1997). In short, social entrepreneurs, like traditional entrepreneurs, have aspirations to develop and grow their enterprise, where growth can be viewed from a range of perspectives, but primarily driven by the provision of a perceived social value (Hynes, 2009).

Most of the relevant literature highlights that social and traditional entrepreneurs are similar, with the general consensus being that they share many of the same inherent personality traits and competencies, but are motivated by different outcomes. The literature contains very little work attempting to differentiate the two groups based on personality trait differences. However, Austin et al. (2006) state that rather than two distinct groups of entrepreneurs coexisting, there is a continuum with the purest forms of either type of at each end, and varying degrees of empathy, social awareness, and profit motive in between.

Leadbetter (1997) asserts that social entrepreneurs are more creative than their traditional counterparts, particularly regarding the management of their enterprise. Their creativity may be borne of necessity, due to the limited funding and resources many social entrepreneurs face. Leadbetter argues that the abundance of charities and social enterprises with flat, open management structures, which subsequent work has identified as a hallmark of a highly innovative and "learning" entrepreneurial organisation (Burns, 2012; Farooq, 2012; Ortenblad, 2004; ), supports this claim.

Dees (1998) describes the social entrepreneur as a "rare breed," citing utilitarian values and passion for social innovation as the basis for their propensity for continuous improvement and innovation. Dees also suggests that the social entrepreneur might exhibit a higher sense of accountability to their stakeholders, referring to them as their "constituents," a term commonly associated with public service. This argument is echoed by others, including Mort et al. (2003), who assert that social entrepreneurs in particular possess the ability to balance the interests of a large range of stakeholders.

The closest study to the research objectives in this paper was executed by Shaw and Carter (2007). After analysing the literature surrounding traditional entrepreneurship, they identified five entrepreneurial themes that they hypothesised would highlight differences between traditional and social enterprises and entrepreneurs: the entrepreneurial process, network embeddedness, the nature of financial risk and profit, the role of individual entrepreneurs in managing and structuring 
Smith, R., Bell, R., \& Watts, H. (2014). Personality trait differences between traditional and social entrepreneurs. Social Enterprise Journal, 10(3), 200-221. http://doi.org/10.1108/SEJ-08-2013-0033

social enterprise, and creativity and innovation. They then constructed an interview designed to highlight these differences.

Shaw and Carter's research exhibits a number of weaknesses in its methodology, and slight disparities in objectives, presenting an opportunity to improve and build upon the research. Methodological weakness can be seen in the limited group targeted for the research. Only social entrepreneurs were interviewed for the study; an examination of the literature surrounding traditional entrepreneurs formed the basis for comparison. In addition, only 45 percent of Shaw and Carter's respondents actually classified themselves as being social entrepreneurs, which casts significant doubt as to the validity of the research findings, as there is no attempt to justify the reason the low percentage of self-identified social entrepreneurs would not impede on the quality of the research.

In relation to research approach and objectives, the focus of Shaw and Carter's research is not based on inherent personality traits of social entrepreneurs, but rather a focus on the process and practice of social entrepreneurs in comparison with traditional entrepreneurs. For example, their research places importance on features such as "network embeddedness" of the enterprise, rather than a more trait-based approach such as "rapport building aptitude" of the entrepreneurs.

Shaw and Carter concluded that, in general, both social and traditional enterprises exhibited each of the five themes outlined above, but that there were differences in the management and leadership style of the enterprise. For example, leading both types of enterprise involves a degree of risk taking, yet a social entrepreneur is far more likely to risk personal credibility than personal financial resources than would a traditional entrepreneur. Findings such as these offer no insight into the intrinsic differences in personality traits between the two. However, it could be argued that the identification of the necessity for different types of process, management, and leadership within the two types of enterprise suggests that there may be distinct personality differences between the two types of entrepreneur.

\section{Measuring Entrepreneurship}

The multidimensional nature of entrepreneurship has led to a wide range of approaches to measuring entrepreneurship. The primary focus of this study is the behavioural side of entrepreneurship, which investigates the differences in personality traits and entrepreneurial characteristics between social and traditional entrepreneurs. Accordingly, this section will focus on measurement methods for the behavioural aspect. 
Smith, R., Bell, R., \& Watts, H. (2014). Personality trait differences between traditional and social entrepreneurs. Social Enterprise Journal, 10(3), 200-221. http://doi.org/10.1108/SEJ-08-2013-0033

Before the differences in personality traits between the two types of entrepreneur can be tested, it is first necessary to examine the debate on how entrepreneurial characteristics and potential can be defined and measured. Over the last half century, several theories and approaches have been developed, resulting in a range of scale and measures for entrepreneurial characteristics.

There is enduring debate amongst academics as to whether the behavioural and personality traits of successful entrepreneurs are born or made. In other words, is the specific disposition required of a successful entrepreneur permanent, inherent, and determined at birth, or can entrepreneurial behaviour be taught and learned (Matthews et al., 2010; Shaver, 2007)? Some academics, particularly from the field of psychology, would argue that personality traits are predetermined, stemming from an individual's psychological core (Ferrer-i-Carbonell and Frijters, 2004; Hollander, 1971), whilst others argue that behaviours and traits evolve over an individual's lifespan, taking into account age, experience, and opportunity (Borghans et al., 2008; Roberts and Caspi, 2003).

It has also been argued, perhaps more logically, that an individual's personality has both elements that are fixed genetically and elements influenced by the external environment. The ratios in which these two sides of the personality are present are widely contested, ranging from 75:25 genetic to environment (Woods, 1998), to 40:60 (Whybrow, 1999). This study concentrates on existing personality traits and not how these may have been acquired. It acknowledges, however, that the 'born or made' debate is a critical starting question when considering the entrepreneurial personality, and that it may offer direction for further investigation when considering any stark differences between social and traditional entrepreneurs.

\section{The Demographic Approach}

The demographic approach to predicting entrepreneurial behaviour uses groupings such as age, race, gender, socio-economic background, and geography to evaluate the likelihood of successful entrepreneurship. The underlying assumption of this approach is that people with similar backgrounds will possess similar characteristics, and some groups will lend themselves more naturally toward entrepreneurship than others (Robinson et al., 1991).

This approach has long been surpassed by more generally-accepted approaches in the literature. It could also be argued that the researchers endorsing this method were substituting demographic filters for actual personality traits. 
Smith, R., Bell, R., \& Watts, H. (2014). Personality trait differences between traditional and social entrepreneurs. Social Enterprise Journal, 10(3), 200-221. http://doi.org/10.1108/SEJ-08-2013-0033

\section{The Cognitive Approach}

The cognitive or attitude approach to entrepreneurial behaviour attempts to ground explanations and measurements of entrepreneurial potential and attributes in psychology. The approach is based on the assumption that attitudes towards entrepreneurship can be measured by interpreting and analysing an individual's "affect, cognition, and conation" of themes related to entrepreneurship (Robinson et al., 1991). It is essentially a series of thought processes (Carsrud and Brannback, 2009) that make up the attitude that an individual has towards entrepreneurship. Planned behaviour theory argues that intentions towards a behavior depend on a set of underlying attitudes (Ajzen, 1991). The subject will either perceive entrepreneurship positively, influencing them to pursue an entrepreneurial career, or dismiss the option because of negative associations, such as fear of risks necessary for entrepreneurialism, like borrowing money or business failure. Kreuger (2003) takes the definition further by asserting that entrepreneurs possess a different set of cognitions towards entrepreneurial themes, such as risk taking and opportunity spotting.

Although this method adds a cerebral dimension and the consideration of psychological process to a more fixed, trait based approach to measuring entrepreneurial potential the literature has since established that measuring the entrepreneurial personality is a complex task (Burns, 2012; Kilby, 2003; Zhao and Seibert, 2006).A criticism of an approach based on entrepreneurial attitudes and intentions is that whilst intentions are the best predictors of future action, there is less understanding of how the intentions lead to action (Bagozzi and Warshaw, 1992; Bird and Schjoedt, 2009), in particular, the role that goals and motives play in predicting behavior. Recent studies into the entrepreneurial cognitions, intentions and their conversion into actual entrepreneurial behaviours have included that by Carsrud and Brannback (2011) who concluded that entrepreneurial motivation required further study to understand this step more fully.

\section{The Trait Approach}

The trait approach to entrepreneurship was pioneered during the 1950's by McClelland et al. (1953) and subsequently echoed by a range of more contemporary academics (Bolton and Thompson, 2004; Bull et al., 1995; Stokes et al., 2010). The approach aims to define and measure entrepreneurship using a series of personality traits and recurrent behaviours most associated with successful entrepreneurs. These personality traits are widely argued as essential personal "ingredients" that an entrepreneur is needs to be successful. Table One outlines the main traits that appear in the literature. The list of academics is not exhaustive, but provides a good overview of the prominent features of each of the traits over the body of work as a whole. 
Smith, R., Bell, R., \& Watts, H. (2014). Personality trait differences between traditional and social entrepreneurs. Social Enterprise Journal, 10(3), 200-221. http://doi.org/10.1108/SEJ-08-2013-0033

Table One: Entrepreneurial Personality Traits

\begin{tabular}{|c|c|}
\hline Personality Trait & References \\
\hline Achievement Motive & $\begin{array}{l}\text { McClelland et al. (1953), Stokes et al. (2010) } \\
\text { Bolton and Thompson (2004), Burns (2012), Kirby } \\
\text { (2003), Wickham (2006), Roberts (1991), } \\
\text { Caird (1991), Carsurd and Brannabck (2011), } \\
\text { Gartner (1985) }\end{array}$ \\
\hline Inner Locus of Control/Drive and Determination & $\begin{array}{l}\text { Burns (2012), Kirby (2003), Bolton and Thompson } \\
\text { (2004), Stoke et al. (2010), Caird (1991), Schjoedt } \\
\text { and Shaver, (2012), Hedner et al. (2011), } \\
\text { Heinrichs et al. (2013) }\end{array}$ \\
\hline Aptitude/Drive for Innovation & $\begin{array}{l}\text { Burns (2012), Kirby (2003), Caird (1991), } \\
\text { Bolton and Thompson (2004), Stokes et al. } \\
\text { (2010), Sarri et al. (2011), Parker (2012), } \\
\text { Wiktorsson and Groth (2011) }\end{array}$ \\
\hline Creativity & $\begin{array}{l}\text { Burns (2012), Kirby (2003), Caird (1991), } \\
\text { Bolton and Thompson (2004), Stokes et al. } \\
\text { (2010), Kirzner (2009), Fillis and Rentschler (2010) }\end{array}$ \\
\hline Risk Taking & $\begin{array}{l}\text { Hornaday (1982), Burns (2012), Bolton and } \\
\text { Thompson (2004), Caird (1991), Macko and } \\
\text { Tyszka (2009), Hebert and Link (2009), Gifford } \\
\text { (2010) }\end{array}$ \\
\hline Problem Solving Style & $\begin{array}{l}\text { Stokes et al. (2010), Harper (2008), Hsieh et. al } \\
\text { (2007), Baron (2008) }\end{array}$ \\
\hline Need for Independence/Autonomy & $\begin{array}{l}\text { Burns (2012), Bolton and Thompson (2004), } \\
\text { Stokes et al (2010), Anokhin et al. (2011), } \\
\text { Oosterbeek et al. (2010) }\end{array}$ \\
\hline Unconventional Perspective/Deviancy & $\begin{array}{l}\text { Burns (2012), Kirby (2003), Simmons and Wiklund } \\
\text { (2011), Bolton and Thompson (2004). }\end{array}$ \\
\hline
\end{tabular}

Perhaps the most widely accepted necessity for an entrepreneur is the need for achievement, or NAch trait (McClelland, 1953; 1961). The N-Ach trait has formed an integral part in many of the studies revolving around trait theory and entrepreneurship. Other traits have been chosen due to the necessity of their presence for the entrepreneur to produce successful ventures. For example, 
Smith, R., Bell, R., \& Watts, H. (2014). Personality trait differences between traditional and social entrepreneurs. Social Enterprise Journal, 10(3), 200-221. http://doi.org/10.1108/SEJ-08-2013-0033

inner locus of control, i.e., the extent to which a person believes that they have control over their own life, is required in order to have the confidence to drive on a venture confidently in the face of external obstacles. Also, innovative tendencies are crucial to ensure the venture stays ahead of competitors in quickly moving markets and to develop new ways of overcoming problems.

Despite the popularity of the trait approach in the literature, the theory has limitations. It could be argued that certain traits can be influenced by the external environment over time. For example, one could argue that the "Inner Locus of Control" and similar traits could be learned as a consequence of a life event, altering an individual's perception on how much control an individual has over his life (Robinson et al, 1991). If personality traits are not always inherent to an individual, it may weaken the test for entrepreneurial potential, as participants are likely to be at different stages in their life, with a multitude of different experiences that could affect their response depending on their current stage or experience.

On balance however, a trait approach towards entrepreneurial potential does offer a good starting point on which to progress the field further, and remains prevalent throughout the literature. In addition, the trait approach is particularly useful for this research, as it is investigating the differences in personality traits between two groups of entrepreneurs.

The literature contains many established tests and scales that make use of personality or character traits to assess the extent to which an individual has entrepreneurial potential. Gallup's 'entrepreneur perceiver' interview, developed by Stanford Research Institute in 1986, consists of 74 questions aimed at determining and identifying entrepreneurial characteristics or entrepreneur life themes (Bolton and Thompson, 2004).

The General Enterprise Tendencies (GET) test was developed by the Small Enterprise Development Unit at Durham Business School and was first published by Caird (1991). The test comprises 54 questions that test five sub scales of the ideal entrepreneurial personality: need for achievement, need for autonomy/independence, creative/innovative tendencies, calculated/moderate risk taking, and drive and determination.

The GET test covers the five most common traits that the literature collectively associates with the ideal entrepreneurial personality and is one of the shortest tests. The test is a popular tool for diagnosing entrepreneurial potential in business students and is licensed for use in industry (Burns, 2012). For these reasons, the GET test is seemingly the most favourable scale for measuring entrepreneurial potential, being relatively succinct, comprehensive, and tested in industry, as well as 
Smith, R., Bell, R., \& Watts, H. (2014). Personality trait differences between traditional and social entrepreneurs. Social Enterprise Journal, 10(3), 200-221. http://doi.org/10.1108/SEJ-08-2013-0033

allowing easy distinction between the five subscales, which will be essential for interpretation of the data.

\section{Research Focus}

It is important to highlight that this research is not intended to validate approaches or established measurement instruments used for investigating the entrepreneurial personality, or even to draw a comparison between the two types of enterprise. Its purpose is to identify any differences between the personality traits of traditional and social entrepreneurs.

This study builds on existing knowledge established by many trait theorists such as McClelland et al. (1953) and Caird (1991) by testing empirically for differences in personality among social and traditional entrepreneurs. It has been established that, on the whole, all entrepreneurs exhibit a similar cluster of characteristics. Despite this, there could be differences between the levels of individual characteristics displayed by the two groups. Acquisition of this knowledge could provide additional insights into the field of entrepreneurial research, and could identify new frameworks for identifying individuals with socially entrepreneurial tendencies.

In addition to the acquisition of new knowledge, there is also a clear argument that new frameworks will be of benefit to industry in terms of identification, recruitment, and retention of candidates with high levels of socially entrepreneurial traits. Such traits are particularly useful within the growing number of highly entrepreneurial social enterprises, charities, and governments. Bornstein and Davies (2010) argue that social entrepreneurship will provide the answers and solutions to the world's problems over the coming years. As such, the attraction of socially entrepreneurial individuals may be important to ensure the growth and success of the aforementioned sectors.

\section{Methodology}

It was decided that the most suitable method for measuring entrepreneurial traits among participants would be Durham Business School's GET test. The test was chosen because, in comparison to other methods, it was relatively short in length and tested for the most widely accepted entrepreneurial traits. In addition, it has a record of being used to test for entrepreneurial potential in both industry and academia (Burns, 2012; Caird, 1991) and is thus validated as a reliable measure of entrepreneurial personality.

The GET test comprises of 54 statements, each associated with one of the entrepreneurial traits being tested: need for achievement, need for autonomy/independence, creative/innovative tendencies, calculated/moderate risk taking, and drive and determination. After each statement, the respondent is required to respond with a categorical "agree" or "disagree," depending on whether 
Smith, R., Bell, R., \& Watts, H. (2014). Personality trait differences between traditional and social entrepreneurs. Social Enterprise Journal, 10(3), 200-221. http://doi.org/10.1108/SEJ-08-2013-0033

they can relate to the statement or not. For a participant to be considered to exhibit the necessary levels of each of the five traits, they must have a minimum attainment score. The minimum attainment score for all categories except "Need for Achievement" is 67 percent. The attainment score for "Need for Achievement" is 75 percent. There is no implication of the overall mean score (Burns, 2012).

This study differentiates itself because it gauges the actual levels of each entrepreneurial trait exhibited rather than measuring the entrepreneurial potential of participants. Measuring trait levels enables the results to be directly analysed and compared between the two groups. For this reason, the test was modified to incorporate a five point measurement scale for responses based on the Likert scale, with "1" representing "Strongly Agree," and " 5 " representing "Strongly Disagree." The scaled scoring technique was adopted because a categorical scale ("agree" or "disagree") would be highly inefficient for comparing the extent to which the two groups exhibited similar or dissimilar levels of each of the five personality dimensions. Using a categorical scale would make it impossible to measure the responses statistically via tests of difference and draw any meaningful conclusion about the extent to which either group exhibits each trait.

The adapted GET test surveys were distributed to over 600 potential respondents identified as either social or traditional entrepreneurs in the United Kingdom who were active in a range of industries. It was sent via email directly to the individual identified entrepreneur as an embedded link to an online version of the adapted survey in the form of a self-administered questionnaire. Two identical, yet separate surveys were sent to the two respective groups, so that answers from either one could be kept separate.

The social entrepreneur participants were selected from a list of social enterprises obtained from two established UK social enterprises and from award shortlists detailing social enterprises that were in the public domain. Each of the participants selected were then individually screened by checking publically available material found online to ensure that all participants met the definition used in this paper. The traditional entrepreneur participants were identified using relevant websites and publications and then screened in a similar way. The list of eligible participants was then independently checked by a second researcher against the definitions used within this research to help support the reliability and robustness of the results. This approach was adopted in order to eliminate individual subjectivity by the use of an objective definition developed from the literature and a consistent interpretation of the classification of the participants sampled. 
It was felt that the choice to self-identify as either a "social" or "traditional" entrepreneur might have resulted in accuracy issues. It has already been explained that definitions of many terms within the discipline of entrepreneurship are varied and contentious, and so the task of self- qualification may have led to inaccuracy, compromising the data.

The sample size for this study comprised of 149 respondents in total. Of these, 74 were social entrepreneurs and 75 were traditional entrepreneurs.

\section{Data Analysis and Results}

A total of 150 responses (75 in either group) were collected before the surveys were closed, although one response was invalid. As a result, the responses from 74 traditional and 75 social entrepreneurs were used in the analysis. Some of the scores had to be numerically inverted, as the structure of the GET test means that the most 'entrepreneurial' scores were represented at " 5 " or " 1 " due to the way the statements were constructed. Once the results had been formatted on a spread sheet, and the necessary scores inverted accordingly, the mean scores for each of the five dimensions of the entrepreneurial personality were calculated for each of the groups, in line with the current use of the GET test. An independent sample t-test was used to compare each of the five dimensions between the two groups to test for significance in the difference of the mean averages at a 95 percent confidence level. Any statistically significant differences between the two groups would highlight areas where the two groups exhibited different levels of the distinct entrepreneurial traits. Where a significant difference in the means was identified, the effect size was calculated using the Eta squared test ${ }^{1}$. The group statistical results are shown in Table Two. The t-Test Results are shown in Table Three.

\footnotetext{
${ }^{1}$ Cohen's guidelines for an Eta squared effect size are that a result of 0.01 is a small effect, 0.06 is a moderate effect and 0.14 is a large effect (Cohen 1988).
} 
Smith, R., Bell, R., \& Watts, H. (2014). Personality trait differences between traditional and social entrepreneurs. Social Enterprise Journal, 10(3), 200-221. http://doi.org/10.1108/SEJ-08-2013-0033

Table Two: Independent Sample t-Test Group Statistics

\begin{tabular}{llcccc} 
GET Dimension & Type of Entrepreneur & N & Mean & $\begin{array}{c}\text { Std. } \\
\text { Deviation }\end{array}$ & $\begin{array}{c}\text { Std. Error } \\
\text { Mean }\end{array}$ \\
\hline Need for Achievement & Traditional & 74 & 3.7078 & .45276 & .05263 \\
& Social & 75 & 3.7521 & .34184 & .03947 \\
\hline Autonomy/Independence & Traditional & 74 & 3.4684 & .45388 & .05276 \\
& Social & 75 & 3.7068 & .58206 & .06721 \\
\hline Creativity/Innovativeness & Traditional & 74 & 3.5574 & .30364 & .03530 \\
& Social & 75 & 3.9409 & .42236 & .04877 \\
\hline Calculated Risk Taking & Traditional & 74 & 3.5520 & .45553 & .05295 \\
& Social & 75 & 3.8779 & .41258 & .04764 \\
\hline Drive and Determination & Traditional & 74 & 3.5866 & .45759 & .05319 \\
& Social & 75 & 3.5561 & .42126 & .04864
\end{tabular}

Table Three: Independent Sample t-Test Results

t-Test for Equality of Mean

\begin{tabular}{|c|c|c|c|c|c|c|c|c|}
\hline \multirow[t]{2}{*}{ GET Dimension } & \multirow[t]{2}{*}{$\mathrm{T}$} & \multirow[t]{2}{*}{$\mathrm{df}$} & \multirow[t]{2}{*}{ Sig. } & \multirow{2}{*}{$\begin{array}{c}\text { Mean } \\
\text { Difference }\end{array}$} & \multirow[t]{2}{*}{$\begin{array}{l}\text { Std. Error } \\
\text { Difference }\end{array}$} & \multicolumn{2}{|c|}{$\begin{array}{l}\text { 95\% Confidence } \\
\text { Interval }\end{array}$} & \multirow[b]{2}{*}{$\mathrm{Eta}^{2}$} \\
\hline & & & & & & Lower & Upper & \\
\hline $\begin{array}{l}\text { Need for } \\
\text { Achievement }\end{array}$ & -0.673 & 135.825 & .502 & -.04430 & .06579 & -.17440 & .08581 & - \\
\hline $\begin{array}{l}\text { Autonomy/ } \\
\text { Independence }\end{array}$ & -2.790 & 139.577 & $.006^{*}$ & -.23842 & .08545 & -.40736 & -.06948 & .050 \\
\hline $\begin{array}{l}\text { Creativity/ } \\
\text { Innovativeness }\end{array}$ & -6.370 & 134.438 & $.000^{*}$ & -.38350 & .06020 & -.50257 & -.26443 & .216 \\
\hline $\begin{array}{l}\text { Calculated Risk } \\
\text { Taking }\end{array}$ & -4.578 & 147.000 & $.000^{*}$ & -.32584 & .07118 & -.46651 & -.18517 & .125 \\
\hline $\begin{array}{l}\text { Drive and } \\
\text { Determination }\end{array}$ & 0.423 & 147.000 & .673 & .03049 & .07204 & -.11188 & .17286 & - \\
\hline
\end{tabular}

*Significant at a 95\% confidence level

\section{Discussion}

The Social Entrepreneurs scored statistically significantly higher in three of the five personality dimensions tested. These dimensions were, in order of effect size or magnitude: "Creativity" (large effect size), "Moderate/Calculated Risk Taking" (medium effect size) and "Need for Autonomy/Independence" (small effect size). There was no statistically significant difference between social and traditional entrepreneurs for the "Drive and Determination" and "Need for Achievement" dimensions. The discussion of the results will be in order of statistical effect size or magnitude of the difference between the two groups. 
Smith, R., Bell, R., \& Watts, H. (2014). Personality trait differences between traditional and social entrepreneurs. Social Enterprise Journal, 10(3), 200-221. http://doi.org/10.1108/SEJ-08-2013-0033

\section{Creativity and Innovativeness}

It was discovered that, within the sample, social entrepreneurs exhibited statistically significant higher levels of creativity, scoring a higher score than traditional entrepreneurs. Although social entrepreneurs exhibited higher levels of creativity and innovativeness, both groups' mean average is above the required benchmark in the GET test of 67 percent, or 3.35 out of a possible 5 ( $M=3.9409$ for social entrepreneurs, and 3.5574 for traditional entrepreneurs). The effect of the type of entrepreneur shows a large effect on "Creativity and Innovativeness" score according to the Eta squared test statistic.

The necessity for entrepreneurs of either type to possess high levels of creativity and innovativeness, featured prominently in the literature review (Burns, 2012; Fillis and Rentschler, 2010; Kirzner, 2009), and the results verify that these assertions are well founded. It must be considered when discussing the results that there is little literature directly comparing the two groups in terms of creativity and innovativeness.

These results are in line with the argument of Leadbetter (1997), who asserts that social entrepreneurs might possess higher levels of creativity and innovativeness than traditional entrepreneurs. When considering this concept rationally, it seems a logical proposition; in order for social entrepreneurs to be successful, they may have to leverage resources within tighter parameters than traditional entrepreneurs. These parameters might include lack of funding, and greater legal or legislative constrictions. Areas such as education, the environment, disability assistance, and public sector issues are generally subject to tight regulations, which can inhibit the ease of innovation and creativity within the enterprise (Bason, 2011; Mulgan, 2007; Walker and Jeanes, 2001). However, questions have been raised as to whether there is a causal link between funding cuts and social entrepreneurialism (Dey and Steyaert, 2012).

The association with a bureaucratic structural configuration (Mintzberg, 1979) may contribute to the perception of social enterprise and non-profit organisations as inflexible, dogmatic entities, unable to sustain themselves through innovation. To counter this assertion, it could be argued that the successful social entrepreneur is aware of his environmental constrictions, and thus takes necessary measures to maximise innovation and information flow at all levels of the organisation, such as encouraging and rewarding entrepreneurial behaviour of employees, and encouraging a flatter, more organic organisational structure (Leadbetter, 1997). Mort et al. (2003) also argue that social entrepreneurs are highly creative in the way that they balance the needs of a very complex range of stakeholders in order to combat the rigidities in their environment, whilst Elkington and Hartigan (2008) maintain that social entrepreneurs habitually create new markets. 
Smith, R., Bell, R., \& Watts, H. (2014). Personality trait differences between traditional and social entrepreneurs. Social Enterprise Journal, 10(3), 200-221. http://doi.org/10.1108/SEJ-08-2013-0033

Historically, academics have argued that the processes of creativity and innovation are associated with profit motive or economics-based concepts such as competition and market creation (Nelson and Winter, 1974; Schumpeter, 1934). Nevertheless, there is a growing awareness of social entrepreneurs and their creative capabilities (Bolton and Thompson, 2004). However, much of the modern literature surrounding entrepreneurship and innovation is centred on emerging, high-tech industries. It could be argued that this traditional conception of innovation influenced the way that literature examining creativity has evolved. As a consequence, social entrepreneurship, being a reasonably recent topic of academic study, has been overlooked.

\section{Moderate/Calculated Risk Taking}

There was also a statistically significant finding when testing for "Moderate/Calculated Risk Taking" amongst social entrepreneurs. As with "Creativity/Innovativeness," the social entrepreneurs scored higher on the GET test than the traditional entrepreneurs, with a high order medium effect size. Both groups scored above the $67 \%$ benchmark in this dimension.

These results are contradictory to much of the literature surrounding the definition of the term "entrepreneur" and how it relates to matters of a social nature. As discussed in the literature review, Arribas et al. (2012) take a highly economic perspective on entrepreneurship. They argue that it is definitive entrepreneurial behaviour to accept risk through personal investment in order to gain financially, which inherently reduces the likelihood of the entrepreneur exhibiting social behaviour. The feeling of ownership towards the surplus of his entrepreneurial activity prevents him from exhibiting social behaviour. In other words, the terms "social" and "entrepreneur" are entirely dichotomous.

This perspective is well reasoned if following the more traditional approach to entrepreneurship. As discussed in the literature review, this research recommends that the term be expanded to adopt a more inclusive approach, adopting the stance of Bolton and Thompson (2004), whereby an entrepreneur is "a person who habitually creates and innovates to build something of recognised value around perceived opportunities."

The expansion of the definition of entrepreneurial risk beyond monetary aspects is key to understanding the results for this personality dimension. While social entrepreneurs may not face the same economic risk or invest any financial capital, they often risk a great deal of personal security to pursue their vision. Not only is the social entrepreneur assuming the professional and emotional risk associated with starting and growing an enterprise, they are doing so with lower wage prospects (Galle, 2010), and no opportunity for capital gain. In effect, social entrepreneurs are trading in the chances of economic prosperity chance to achieve their social visions. To do so, they 
Smith, R., Bell, R., \& Watts, H. (2014). Personality trait differences between traditional and social entrepreneurs. Social Enterprise Journal, 10(3), 200-221. http://doi.org/10.1108/SEJ-08-2013-0033

must often compromise the financial security of their families by leaving well-paid jobs or converting their current enterprise into a non-profit venture (Bornstein and Davies, 2010).

The additional parameters of risk can be developed further to expose multiple layers with which social entrepreneurs might engage, whilst traditional entrepreneurs might not. Mair and Sharma (2012) stress that greater levels of accountability are needed in the social sector due to a shift away from a performance-based, profit-maximising business model to one a model in which transparency and a return to stakeholders are expected. Furthermore, it could be argued from a Utilitarian perspective that the level of risk-taking behaviour required from any type of entrepreneur depends on the number of stakeholders reliant on the success of the enterprise. On the whole, social enterprises are reputed for being stakeholder-oriented organisations (Low, 2006), as they are owned by the community instead of shareholders as with a traditional enterprise (Pearce, 2003).

After critical evaluation of the results, a logical conclusion can be drawn that social entrepreneurs exhibit higher levels of risk taking than their traditional counterparts.

\section{Need for Autonomy/Independence}

The results of testing for levels of the "Need for Autonomy/Independence" trait between social and traditional entrepreneurs revealed a difference in scores, with social entrepreneurs scoring higher than their traditional counterparts. The difference was statistically significant, representing a small effect size. Both groups attained a mean average above the 67 percent threshold to be considered entrepreneurial in terms of the need for autonomy.

These results are particularly interesting, as it could be argued that the results are due in part to a social entrepreneur's prosocial personality (Ernst, 2012). The prosocial personality has been described as having consideration for and helping others, feeling social responsibility, care orientation, and sympathy (Eisenberg et al., 2002). Possessing a prosocial personality means that social entrepreneurs would strive for collaboration and consensus when making decisions, instead of going their own way without regard to the views of others. The results do not an indicate that social entrepreneurs exhibit only prosocial personality traits, but the results may cast question upon the definition of the "prosocial personality," or whether it is exclusive to the social entrepreneur.

An assertion that might be able to explain the different levels of need for autonomy can be found by referring back to the previous discussion about risk. If social entrepreneurs inherently take more risks, it could be argued that taking risks is an attribute of an individual who is confident to stand 
Smith, R., Bell, R., \& Watts, H. (2014). Personality trait differences between traditional and social entrepreneurs. Social Enterprise Journal, 10(3), 200-221. http://doi.org/10.1108/SEJ-08-2013-0033

independently and be held accountable for his own actions, compared to the traditional entrepreneur. This could explain the difference in mean scores. Comparisons can be drawn here between the social entrepreneur and the socially deviant "moral entrepreneur" (Becker, 1963). Becker refers to the moral entrepreneur as a "humanitarian crusader," more concerned with the ends than the means of their endeavour. This notion bears striking relevance to the connotations of the results of this section. Following the premise that social entrepreneurs are bigger risk takers, with high levels of a need for autonomy that departs from Ernst's prosocial conception of personality, it could be argued that the modern phenomenon of the social entrepreneur is in fact Becker's moral entrepreneur, with the addition of the acumen, skills and drive to run an enterprising organisation.

\section{Drive and Determination}

It was discovered that traditional entrepreneurs exhibited a marginally higher level of drive and determination than social entrepreneurs, although this difference was not statistically significant. This was the only dimension where traditional entrepreneurs scored a higher mean average than their social counterparts. Again, both groups scored higher than the minimum benchmark score of $67 \%$.

The results for this personality dimension may not be as surprising as others. Whilst conducting the research, it was noted that many of the statements within the GET test for this dimension are structured in such a way that the responses given by social entrepreneurs may not match the answers that the GET test would identify as entrepreneurial. If it is accepted that social entrepreneurs exhibit higher levels of humanitarianism and sympathy towards others, social entrepreneurs, would not answer 'agree' to statements such as "People mostly get what they deserve."

Using the GET test to measure the inherent differences between social and traditional entrepreneurs reveals an inherent weakness, as the results would be skewed in favour of the latter group achieving a higher score. However, the difference between the means is marginal and retesting with a much larger sample size of respondents would be necessary to draw solid conclusions that could suggest the development of a new tool to measure the overall entrepreneurial potential of all groups of entrepreneur, as well as testing for differences between them.

It must be noted however, that not all of the statements in this section might lead social entrepreneurs to respond in a manner identifying themselves as less entrepreneurial than traditional entrepreneurs. The other statements helped to identify other areas within the broader "Drive and Determination" category, such as the "Internal Locus of Control," which is a heavily 
Smith, R., Bell, R., \& Watts, H. (2014). Personality trait differences between traditional and social entrepreneurs. Social Enterprise Journal, 10(3), 200-221. http://doi.org/10.1108/SEJ-08-2013-0033

featured theme in the literature surrounding this dimension (Heinrichs and Sascha, 2013; Schjoedt and Shaver 2012). Without intricate dissemination of individual scores and themes for each statement, it would be problematic to interpret what proportion of the statements might impact the accuracy of the findings.

\section{Need for Achievement}

In the sample, social entrepreneurs exhibited slightly higher levels of the trait "Need for Achievement" than their traditional counterparts, although the difference was not statistically significant. "Need for Achievement" is one of the most widely accepted attributes of the successful entrepreneur (Casrud and Brannback, 2011; Gartner, 1985; McClelland et al., 1953). It could be argued that the "Need for Achievement" is a fundamental trait for any entrepreneur, irrespective of the type of enterprise they run. Interestingly, whilst the social entrepreneurs achieved the minimum benchmark of $75 \%$, or 3.75 out of a possible $5(M=3.7521)$, the traditional entrepreneurs failed to do so $(M=3.7078)$. It could be argued that many social entrepreneurs aspire to achieve for multiple stakeholders in their enterprise, and a higher score might be indicative of the desire to serve many stakeholders.

It should be noted however, that where results return such insignificant findings, retesting with a larger sample size is necessary in order to establish any statistically significant differences that there might be between the two groups, or verify that the achievement motive is a trait that both types of entrepreneur possess in equal measures.

\section{Limitations and Future Research}

Although the results of the research have identified a number of differences in personality between social and traditional entrepreneurs, it was also subject to a number of limitations.

The limited sample size of participants provides restricted generalisation of the findings, presenting a starting point for further research. In order for the results to be validated, it would be essential to carry out a retest using a larger sample size. It would also be interesting to discover if the inclusion of entrepreneurs from a range of nationalities within the sample would present different findings. It could be argued that cultural differences within the sample might alter the findings. Within the broader variables of 'social' and 'traditional' entrepreneur, this could verify the results statistically on a wider level. It could also establish a starting point for researchers wishing to examine the entrepreneurial personality from a transnational perspective. 
Smith, R., Bell, R., \& Watts, H. (2014). Personality trait differences between traditional and social entrepreneurs. Social Enterprise Journal, 10(3), 200-221. http://doi.org/10.1108/SEJ-08-2013-0033

Whilst each participant was individually screened based on the information that could be obtained regarding their current enterprise/project and the definitions adopted in this research, it is accepted that in some cases it is possible that a social entrepreneur could potentially be currently connected with a commercial enterprise and vice versa. In order to keep a level of external objectivity this research has classified the individual participants based on their current entrepreneurial activities. It is accepted that this is a potential limitation to this research; however this approach was able to offer a robust and objective standardized classification system. In addition, as the entrepreneurs included within this study were individually screened and the questionnaires were sent addressed to the individual entrepreneurs this should improve the reliability and robustness of the data collected.

This research has focused solely on the entrepreneurial traits that are measured within the GET test, namely, creativity, calculated risk taking, need for autonomy, drive and determination, and the need for achievement. It is acknowledged that other behaviours may also be different between the two entrepreneurial groups. For example, this research has not considered the impact of social influences on the behavior of entrepreneurs. The Bolton Thompson Entrepreneur Indicator (BTEI) (Bolton and Thompson, 2003) considers six key entrepreneurial character themes, which include a social dimension which may influence entrepreneurial motivation and behaviour. Further research could help to provide additional insights into the social dimension of entrepreneurs running social enterprises compared to those running commercial enterprises, which will help to complement the findings of this research.

Although this research supports the view of many academics that social entrepreneurs exhibit the same range of entrepreneurial personality traits as traditional entrepreneurs, it also has implications for advancing the field of research in entrepreneurship. These results suggest that academia's perception of social entrepreneurs might need to be expanded, as the outcomes of this research directly challenge the view that entrepreneurial and social personalities are dichotomous (Arribas et al.2012; Cho, 2006) and indicates that the social entrepreneur may be more enterprising as a result of operating within tighter parameters.

Further research might also include an exploration of the links between the social entrepreneur and the moral entrepreneur. The links could be examined after re-testing for differences between social and traditional entrepreneurs, within the specified condition for verifying the results, and comparing the newly established personality profile of the social entrepreneur with extant sociological literature surrounding the moral entrepreneur. Such knowledge would enhance understanding of 
Smith, R., Bell, R., \& Watts, H. (2014). Personality trait differences between traditional and social entrepreneurs. Social Enterprise Journal, 10(3), 200-221. http://doi.org/10.1108/SEJ-08-2013-0033

the evolution of social entrepreneurship and would provide a perspective of the social entrepreneur as a moral entrepreneur, mechanising business and commercial techniques in order to implement his social and moral convictions.

\section{Conclusion}

The results of the research validate the necessity for such an investigation to be conducted. With social entrepreneurs' scoring statistically significantly higher in three out of the five personality dimensions being tested, with small, medium and large effect sizes, it is clear that there are distinct differences between the levels of entrepreneurial personality traits exhibited by the two groups. This finding provides quantitative support for the premise that social entrepreneurs differ in some ways from commercial entrepreneurs and as such are distinct from commercial entrepreneurs (Duncan, 2009).

Within the sample, social entrepreneurs exhibited statistically significant higher levels of "Creativity and Innovativeness," "Moderate/Calculated Risk Taking," and "Need for Autonomy/Independence," indicating that there is a possibility that social entrepreneurs are inherently more entrepreneurial in academically conventional terms than their traditional counterparts. Arguably, this is a necessity for the success, or even survival, of social enterprises. Social enterprises face the problem of leveraging resources within tight parameters, including limited funding and complex legal and legislative constrictions, which can potentially stifle the ability to innovate and be creative (Bason, 2011). In addition, social entrepreneurs may need to balance the needs of a range of stakeholders to meet the challenges of double and triple-bottom line business models.

Recommendations have also been made to follow up the research by investigating whether cultural differences influence levels of entrepreneurial personality traits. It has also been recommended that the relationship be explored between the moral entrepreneur found in sociological literature, and the social entrepreneur, as overlapping characteristics were identified during the research process. An interdisciplinary approach would allow the application of the newly established personality profile of the social entrepreneur, and advance the field by exploring untested academic territory.

The findings of this research also have the potential to make a contribution towards the field of entrepreneurship education. An understanding of the inherent personality differences between traditional and social entrepreneurs could progress the development of training and education programmes for current and aspiring entrepreneurs by creating a specialised approach to training 
Smith, R., Bell, R., \& Watts, H. (2014). Personality trait differences between traditional and social entrepreneurs. Social Enterprise Journal, 10(3), 200-221. http://doi.org/10.1108/SEJ-08-2013-0033

for either group. In addition, because social entrepreneurs are beholden to a wider variety and number of stakeholders, they may require additional or supplemental education in business planning to account for this (Conway, 2008). 
Smith, R., Bell, R., \& Watts, H. (2014). Personality trait differences between traditional and social entrepreneurs. Social Enterprise Journal, 10(3), 200-221. http://doi.org/10.1108/SEJ-08-2013-0033

\section{References}

Anokhin, S., Dietmar, G. and Robert, D. H. (2013), "The journey from novice to serial entrepreneurship in China and Germany, are the drivers the same." Managing Global Transitions, Vol.6 No.2, pp.117-142.

Arribas, I. (2012), “Are social and entrepreneurial attitudes compatible?: A behavioral and selfperceptional analysis", Management Decision, Vol. 50 No. 10, pp. 1739-1757.

Austin, J., Stevenson, H. and Wei-Skillern, J. (2006),"Social and commercial entrepreneurship: same, different, or both?", Entrepreneurship Theory and Practice, Vol. 30 No. 1, pp. 1-22.

Bagozzi, R.P. and Warshaw, P.R. (1992), "An examination of the etiology of the attitude-behavior relation for goal-directed behaviors", Multivariate Behavioral Research, Vol. 27 No.4, pp. 601-634.

Bason, C. (2011), Leading Public Sector Innovation: Co-creating for a Better Society, The Policy Press, London, UK.

Baron, R. A. (2008),"The role of affect in the entrepreneurial process", Academy of Management Review", Vol. 33 No. 2, pp. 328-340.

Becker, H. (1963), Outsiders: Studies in the Sociology of Deviance, Free Press, New York, NY.

Bird, B. and Schjoedt, L. (2009), "Entrepreneurial behavior: Its nature, scope, recent research, and agenda for future research", in Carsrud, A. and Brannback, M. (Ed.), Understanding the Entrepreneurial Mind: Opening the Black Box, Springer: Heidelberg, 327-358.

Bolton, W.K. and Thompson, J.L. (2003), The Entrepreneur in Focus: Achieve your Potential, Thomson, London, UK.

Bolton, W.K. and Thompson, J.L. (2004), Entrepreneurs: Talent, Temperament, Technique, Butterworth Heinemann, Oxford, UK.

Borghans, L., Duckworth, A.L., Heckman, J.J. and Ter Weel, B. (2008), “The economics and psychology of personality traits", Journal of Human Resources, Vol. 43 No. 4, pp. 972-1059.

Bornstein, D., and Davis, S. (2010), Social Entrepreneurship: What Everyone Needs to Know, Oxford University Press, Oxford, UK.

Burns, P. (2012), Corporate Entrepreneurship: Building the Entrepreneurial Organisation, Palgrave MacMillan, Basingstoke, UK. 
Smith, R., Bell, R., \& Watts, H. (2014). Personality trait differences between traditional and social entrepreneurs. Social Enterprise Journal, 10(3), 200-221. http://doi.org/10.1108/SEJ-08-2013-0033

Caird, S. (1991), "The enterprising tendency of occupational groups", International Small Business Journal, Vol. 19 No. 4, pp. 75-81.

Carsrud, A.L. and Brannback, M. (2009), Understanding the Entrepreneurial Mind: Opening the Black Box, Springer, Heidelberg, Germany.

Carsrud, A. and Brännback, M. (2011), "Entrepreneurial motivations: What do we still need to know?", Journal of Small Business Management, Vol. 49 No. 1, pp. 9-26.

Cho, A.H. (2006), "Politics, values and social entrepreneurship: a critical appraisal" in Mair, J., Robinson, J. and Hockerts, K. (Ed.), Social Entrepreneurship, Palgrave Macmillan, New York, NY. Cohen, J. (1988), Statistical Power Analysis for the Behavioural Sciences, Lawrence Erlbaum, New Jersey, NJ.

Conway, C. (2008), "Business planning training for social enterprise", Social Enterprise Journal, Vol. 4 No. 1 , pp. $57-73$.

Ferrer-i-Carbonel, A. and Frijters, P. (2004),"The effect of methodology on the determinants of happiness", Economic Journal, Vol. 114 No. 497, pp. 641-659.

Dees, J. G. (1998), "The meaning of social entrepreneurship", working paper, Kauffman Center for Entrepreneurial Leadership, 31 October, available at: http://www.redalmarza.cl/ing/pdf/TheMeaningofsocialEntrepreneurship.pdf (accessed 28th March 2013).

Dey, P. and Steyaert, C. (2012), "Social entrepreneurship: critique and the radical enactment of the social", Social Enterprise Journal, Vol. 8 No. 2, pp. 90-107.

Duncan, E. (2009), A Grounded Theory Study on Social Entrepreneurship: Comparison of Traditional and Social Entrepreneurial Nonprofit Model, Lambert Academic, Koln, Germany.

Eisenberg, N., Guthrie, I.K., Cumberland, A., Murphy, B.C., Shepard, S.A., Zhou, Q., Carlo, G. (2002), "Prosocial development in early adulthood: A longitudinal study", Journal of Personality and Social Psychology, Vol. 82 No. 6, pp. 993-1006.

Elkington, J. and Hartigan, P. (2008), The Power of Unreasonable People: How Social Entrepreneurs Create Markets that Change the World, Harvard Business School Press, Boston, UK. 
Smith, R., Bell, R., \& Watts, H. (2014). Personality trait differences between traditional and social entrepreneurs. Social Enterprise Journal, 10(3), 200-221. http://doi.org/10.1108/SEJ-08-2013-0033

Ernst, K. (2012), "Social entrepreneurs and their personality", in Volkmann, C.K., Tokarski, K.O. and Ernst, K. (Ed.), Social Entrepreneurship and Social Business, An Introduction and Discussion with Case Studies, Springer, Heidelberg, pp. 51-64.

Farooq, O. (2012), "Why are some firms more innovative than others? Exploring the role of learning organization components", Global Business and Organizational Excellence, Vol. 31 No. 6, pp. 42-49.

Ferrer-i-Carbonell, A. and Frijters, P. (2004), "How important is methodology for the estimated of the determinants of happiness?", The Economic Journal, Vol. 114 No. 497, pp. 641-659.

Fillis, I. and Rentschler, R. (2010), "The role of creativity in entrepreneurship", Journal of enterprising culture, Vol. 18 No. 1 , pp. 49-81.

Galle, B. (2010),"Keep charity charitable", Texas Law Review, Vol. 88, pp. 10-12.

Gartner, W. (1985), "A conceptual framework for describing the phenomenon of new venture creation", Academy of Management Review, Vol. 10 No.4, pp. 696-706.

Gawell, M. (2013), "Social entrepreneurship - innovative challengers or adjustable followers?", Social Enterprise Journal, Vol. 9 No. 2, pp. 203-220.

Germak, A.J. and Robinson, J.A. (2013), "Exploring the motivation of nascent social entrepreneurs", Journal of Social Entrepreneurship, DOI 10.1080/19420676.2013.820781.

Gifford, S. (2010), Handbook of Entrepreneurship Research: Risk and Uncertainty, Springer, New York, NY.

Harper, D. A. (2008),"Towards a theory of entrepreneurial teams", Journal of Business Venturing, Vol. 23 No.6, pp. 613-626.

Haugh, H. (2005), "A research agenda for social entrepreneurship", Social Enterprise Journal, Vol. 1 No. 1, pp. 1-12.

Hedner, T., Adli, A. and Magnus, K. (2011), "Entrepreneurial resilience." Annals of Innovation and Entrepreneurship 2.1, Vol. 1 No.1, pp. 1-4.

Heinrichs, S. and Sascha, W. (2013),"Who becomes an entrepreneur? A 30-years-review of individual-level research and an agenda for future research", Leibniz Information Centre for Economics, available at: http://www.econstor.eu/handle/10419/68590 (accessed 24 ${ }^{\text {th }}$ March 2013). 
Smith, R., Bell, R., \& Watts, H. (2014). Personality trait differences between traditional and social entrepreneurs. Social Enterprise Journal, 10(3), 200-221. http://doi.org/10.1108/SEJ-08-2013-0033

Hollander, E. P. (1971), Principles and Methods of Social Psychology, Oxford University Press, Oxford, UK.

Hornaday, J.A. (1982), "Research about living entrepreneurs", in Kent, C.A., Sexton, D.L., Vesper, K.H. (Ed.), Encyclopedia of Entrepreneurship, Prentice Hall, Englewood Cliffs, NJ, pp. 20-34.

Hebert, R. F. and Link, A. (2009), A History of Entrepreneurship, Routledge, London, UK.

Hsieh, C., Nickerson, J.A. and Zenger, T.R. (2007), “Opportunity discovery, problem solving, and the entrepreneurial theory of the firm", Journal of Management Studies, Vol. 44 No. 7, pp. 1255-1277.

Hynes, B. (2009), "Growing the social enterprise - issues and challenges", Social Enterprise Journal, Vol. 5 No. 2, pp. 114-125.

Jones, R., Latham, J. and Betta, M. (2008) "Narrative construction of the social entrepreneurial identity", International Journal of Entrepreneurial Behaviour and Research, Vol. 14 No. 5, pp. 330 345.

Kilby, P. (1971) "Hunting the Heffalump", In Kilby, P. (Ed.), Entrepreneurship and Economic Development, The Free Press, New York, pp. 1-40.

Kilby, P. (2003), “The Heffalump Revisited”, Journal of International Entrepreneurship, Vol. 1 No. 2, pp. 13-29.

Kirby, D. A. (2003), Entrepreneurship, McGraw Hill Education, Maidenhead, UK.

Kirzner, I. M. (2009), "The alert and creative entrepreneur a clarification" Small Business Economics, Vol. 32 No. 2, pp. 145-152.

Krueger, N. F. (2003), The Cognitive Psychology of Entrepreneurship, Handbook of Entrepreneurship Research, Kluwer, Manchester, UK.

Leadbeater, C. (1997), The Rise of the Social Entrepreneur, Demos, London, UK.

Low, C. (2006), "A framework for the governance of social enterprise", International Journal of Social Economics, Vol. 33 No. 5-6, pp. 376-385.

Macko, A. and Tadeusz. T. (2009),"Entrepreneurship and risk taking" Applied Psychology, Vol. 58 No. 3, pp. 469-487. 
Smith, R., Bell, R., \& Watts, H. (2014). Personality trait differences between traditional and social entrepreneurs. Social Enterprise Journal, 10(3), 200-221. http://doi.org/10.1108/SEJ-08-2013-0033

Mair, J. and Sharma, S. (2012), "Performance measurement and social entrepreneurship", in Volkmann, C.K., Tokarski, K.O. and Ernst, K. (Eds.), Social Entrepreneurship and Social Business: An Introduction and Discussion with Case Studies, Springer, Wiesbaden, Germany, pp. 175-189.

Matthews, R.B., Stowe, C.R.B. and Jenkins, G.K. (2010)," Entrepreneurs - born or made?", Proceedings of the Academy of Entrepreneurship, Vol. 17 No. 1, pp. 49-55.

McClelland, D. C., Atkinson. J. W., Clark, R. A. and Lowell, L. (1953), The Achievement Motive, Appleton-Century-Crofts, New York, NY.

McClelland, D. (1961), The Achieving Society, Van Nostrand, Princeton, NJ.

Mintzberg, H. (1979), The Structuring of Organizations, A Synthesis of The Research, Prentice Hall, Englewood Cliffs, NJ.

Mort, G., Weerawardena, J. and Carnegie, K. (2003)," Social entrepreneurship: Toward conceptualisation", International Journal of Non-profit and Voluntary Sector Marketing, Vol. 8 No. 1, pp. 76-88.

Mulgan, G . (2007), Ready or Not? Taking Public Sector Seriously, Working Paper, NESTA, London, 3 April, available at: http://www.nesta.org.uk/library/documents/readyornot.pdf (accessed 18th April 2013).

Martin, R.L. and Osberg, S. (2007), "Social entrepreneurship: The case for definition", Stanford Social Innovation Review, Vol. Spring, pp. 27-39.

Mason, C. (2012), "Up for grabs: A critical discourse analysis of social entrepreneurship discourse in the United Kingdom", Social Enterprise Journal, vol. 8 No. 2, pp. 123-140.

Nelson, R. and Winter, S. G. (1974)," Neoclassical vs. evolutionary theories of economic growth, critique and prospectus", The Economic Journal , Vol. 84 No. 336, pp. 886-905.

Onuoha G., (2007) “Entrepreneurship”, AIST International Journal, Vol. 10, pp. 20-32.

Oosterbeek, H., Mirjam. V.P. and Auke, I. (2010), "The impact of entrepreneurship education on entrepreneurship skills and motivation", European Economic Review, Vol. 54 No.3, pp. 442-454.

Örtenblad, A. (2004), "The learning organization: towards an integrated model", The Learning Organization, Vol. 11 No. 2, pp. 129-144. 
Smith, R., Bell, R., \& Watts, H. (2014). Personality trait differences between traditional and social entrepreneurs. Social Enterprise Journal, 10(3), 200-221. http://doi.org/10.1108/SEJ-08-2013-0033

Parker, S. C. (2012), "Theories of entrepreneurship, innovation and the business cycle", Journal of Economic Surveys, Vol. 26 No.3, pp. 377-394.

Pearce, J. (2003), Social Enterprise in Any Town, Calouste Gulbenkian Foundation, London, UK.

Pomerantz, M. (2003), "The business of social entrepreneurship in a down economy", Business, Vol. 25 No.3, pp. 25-30.

Sarri, K., Bakouros, I. and Petridou, E. (2010), "Entrepreneur training for creativity and innovation", Journal of European Industrial Training, Vol. 34 No.3, pp. 270-288.

Roberts, E. B. (1991), Entrepreneurs in High-Technology, Oxford, Oxford University Press.

Roberts, B. W. and Caspi, A.U.M S. (2003), The Cumulative Continuity Model of Personality Development: Striking a Balance Between Continuity and Change in Personality Traits Across the Life Course, Understanding Human Development: Dialogues with Lifespan Psychology, Klewer, Dordrecht, Germany.

Robinson, P.B., Stimpson, D.V., Huefner, J.C., Hunt, H.K. (1991), “An attitude approach to the prediction of entrepreneurship", Entrepreneurship Theory \& Practice, Vol. 15 No 1, pp. 13-30.

Schjoedt, L. and Shaver, K. (2012), "Development and validation of a locus of control scale for the entrepreneurship domain", Small Business Economics, Vol. 39 No.3, pp. 713-726.

Schumpeter J. A. (1965), Economic Theory and Entrepreneurial History: Explorations in Enterprise, Harvard University Press, Cambridge, MA.

Schumpeter, J. A. (1934), The Theory of Economic Development, Harvard University Press, Cambridge, MA.

Shaver, K. (2007), "Psychological methods in entrepreneurship research" in Baum, R.J., Frese, M., Baron, R.A. (Ed.), The Psychology of Entrepreneurship, Routledge, Englewoods, NJ, 335-346.

Shaw, E. and Carter, S. (2007), "Social entrepreneurship theoretical antecedents and empirical analysis of entrepreneurial processes and outcomes", Journal of Small Business and Enterprise Development, Vol. 14 No. 3, pp. 418-434.

Simmons, S. and Wiklund, J. (2011), "Stigma and entrepreneurial failure: implications for entrepreneurs' career choices", Working Paper, Imperial College, London, available at: https://workspace.imperial.ac.uk/businessschool/Public/SIMMONS\%20\%20Stigma\%20and\%20Entre 
Smith, R., Bell, R., \& Watts, H. (2014). Personality trait differences between traditional and social entrepreneurs. Social Enterprise Journal, 10(3), 200-221. http://doi.org/10.1108/SEJ-08-2013-0033

preneurial\%20Failure,\%20Implication\%20for\%20Entrepreneurs\%20Careers\%20Choices.pdf (accessed 1st April 2013).

Stokes, D. and Wilson, N. (2010), Small Business Management and Entrepreneurship, Cengage, Hampshire, UK.

Stokes, D., Wilson, N. and Mador, M. (2010), Entrepreneurship, Cengage, Hampshire, UK.

Timmons, J. A. (1989), The Entrepreneurial Mind, Brick House Publishing, Andover, UK.

Tracey, P. and Phillips, N. (2007) "The distinctive challenge of educating social entrepreneurs" Academy of Management Learning and Education, Vol. 6 No. 2, pp. 264-271.

Urban, B. (2008), "Social entrepreneurship in South Africa: delineating the construct with associated skills", International Journal of Entrepreneurial Behaviour and Research, Vol. 14 No. 5, pp.346-364.

Walker, R. M. and Jeanes. E. (2001), "Innovation in a regulated service, the case of English housing associations", Public Management Review, Vol. 3 No.4, pp. 525-550.

Whybrow, P. C. (1999), A Mood Apart, A Thinker's Guide to Emotion and Its Disorder, Picador, Oxford, UK.

Wickham, P. A. (2006), Strategic Entrepreneurship, Prentice Hall, Harlow, UK.

Woods, B. (1998), Applying Psychology to Sport, Hodder Education, London, UK.

Wiktorsson, M. and Groth, M. (2011), "Conditions for innovation: insights from a multi-case study", Journal of technology management and innovation, Vol. 6 No.2, pp. 203-217.

Zhao, H. and Seibert, S. E. (2006),"The big five personality dimensions and entrepreneurial status, a meta-analytical review", Journal of Applied Psychology, Vol. 91 No. 2, pp. 259-271. 